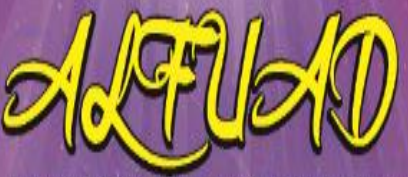

JURNAL ILMIAH SOSIAL KEAGAMAAN
ALFUAD JOURNAL, 4 (2), 2020,(76-87)

(E-ISSN 2714-7606 P-ISSN 2614-4786 )

Available online at

http://ecampus.iainbatusangkar.ac.id/ojs/index.php/alfuad

\title{
APPLICATION OF SPACE MAKERSPACES IN BATUSANGKAR IAIN LIBRARY: LIBRARY DEVELOPMENT STRATEGY
}

\section{Tri Yuliani}

Institut Agama Islam Negeri Batusangkar, Indonesia

E-mail: triyuliani@iainbatusangkar.ac.id
Abstract: In this paper, we describe the maker concept, movement and culture and its impact on and relationship with libraries. We provide a comprehensive review of library makerspaces in IAIN Batusangkar supported by several case studies. We intend this review to be used as a reference resource or tool for libraries planning to implement a new makerspace.

Keywords: Makerspace, Library, Learning, Digital, Technologies, Maker

\section{INTRODUCTION}

The condition of libraries in Indonesia in general shows a worrisome condition, $90 \%$ are stated not to have complete infrastructure, including human resources (Dian, 2011: 27). Inf rastructure including the concept of infrastructure, spatial planning and governance in the library must be able to support user friendly services. (Anna, 2018: 28). This has an impact on the quality of library services and ultimately threatens library development. When a parent body no longer feels the essential essence of a library, then Adios! The library will become an organism that lives and doesn't want to die (Dian, 2011: 27)."Libraries need to change their paradigm to be technology-based and to develop themselves more, so that as a source of library learning, it remains the backbone of the nation in gaining knowledge and deepening knowledge," said UGM Vice Chancellor for Academic and Student
Affairs, Prof. dr. Iwan Dwiprahasto, M.Med.Sc., Ph.D, in the 2016 Indonesian Librarian Seminar and Workshop, Thursday $(10 / 13)$ at the UGM Library.

Based on Law number 43 of 2007 , libraries are institutions that manage collections, print works, and record works in a professional manner with a standardized system to meet the educational, research, preservation, information and recreation needs of the visitors. The library is held based on the principles of lifelong learning, democracy, justice, professionalism, openness, measurement, and partnership. The library functions as a vehicle for education, research, preservation, information, and recreation to increase the intelligence and empowerment of the nation. The library aims to provide services to users, increase reading fondness, and expand insight and knowledge to educate the nation's life (Romi, 2020). 
Substitution of library service concepts starts towards the library that collaborates with users and between users and users. Collaboration that can be used like doing a job together so that the work can be completed more quickly and time-efficient as well as the existence of communication between users that lead to intense social interaction. There fore the library must build a container that can integrate it so that it not only provides information but also a means to do work together (Reza, 2018:2)

Institutions that educate the nation must be balanced with current technological developments. As an organization that continues to innovate and grow (Growing Organism), the library continues to experience transformation from time to time. The library paradigm like a book building has begun to be abandoned by the public. The library is not a physical place that provides a variety of sources of information, but also a place where everyone can do social interaction and also develop ideas and creativity in the library (Mursyid, 2019: 29$30)$.

The library no longer provides heaps of physical collections that take up a lot of space. Technological developments have led to the electronic phenomenon (e). Almost all library collections have been transformed into electronic collections, ranging from ebooks, e-magazines, ejournal, and others. This allows the physical library collection to decrease and on one side of the empty library space to increase.

Another view is that the existence of public and community spaces is increasingly needed nowadays. Modern society's life cannot be separated from the phenomenon of socializing and collaborating in various fields as one form of knowledge sharing culture. This is merely for the development of the talents and creativity of everyone. However, competition in the global era requires everyone to have certain competencies.

In the midst of these conditions, the library continues to experience development and has now arrived at the era of makerspace. Initially, makerspace is a gathering place for communities in order to pour their creativity into a product. Makerspace was originally in public places and not in a library. However, along with the times, the existence of makerspace is increasingly needed. In this condition, makerspace has become a new trend in the library which is actually a learning tool in the community.

Makerspace makes the library no longer a silent space, but rather a space of expression, creation and openness for the development of creativity and problem solving that ends in an outcome (product) of creativity itself. Makerspace became the fifth generation in library development. With the existence of this Makerspace, the library participates in the development of 
community soft skills. There are many activities that can be done in makerspace, ranging from soldering, cutting, printing images with 3D printing, and others. With this makerspace, someone can increase their innovation and pour directly in the form of products. Later, someone can not only read books in the library, but can also repair cellphones, laptops, and make other products in the library directly.

Unfortunately, this makerspace phenomenon in Indonesia is still not very familiar. Indonesia is still lagging behind when compared to neighboring countries, Singapore for example. Singapore is a country that is known to be active in the field of makerspace and has a lot of makerspace spaces. In fact, the country was ranked 7 th in the Global Innovation Index in 2014 and led among Asian countries (https://id.techinasia.com/d listedmakerspace-di-jakarta/).

Furthermore, in this paper we want to discuss more deeply about what is the makerspace in the library and what competencies need to be prepared by a librarian.

\section{METHOD}

The method used in this research is literature study research method with a qualitative approach. Literature study is looking for theoretical references that are relevant to the case or problem found. Literature studies tend to obtain a data and theory that comes from books that are related to the problem being discussed. Reference sources used such as books, journals, articles, research reports and online references are credible and valid. The purpose of using literature studies is to reinforce the problems that are being discussed and as a theory used as a basis for the Makerspace in the library.

The data collection technique used is to collect relevant literature that is a document relating to the problem. Documents are records of events that have passed and the form of such documents such as writing, pictures, or monumental works of someone (Sugiyono, 2013). According to Bogdan (in Sugiyono, 2013) states that the results of research are also increasingly credible if supported by photographs or academic papers and art that already exist. The literature used is secondary data in the form of references to books, journals, scientific articles and others.

\section{RESULTS AND DISCUSSIONS}

\section{Makerspace: A Sustainability}

Basically, makerspace is a gathering place for makers to collaborate and exchange ideas to produce something. (Alyssa Pisarski, 2014: 13) in his paper entitled Finding a place for tween; Makerspace and Libraries writes:

"Makerspaces consist of a
community of makers that come
together to create by sharing tools,
skills, and knowledge-creating a
place to learn a new skill, to become
a creator, to connect with a


community and build friendships, or to gain access to specialized equipment."

From this it can be understood that makerspace consists of a community of makers who come together to create something by sharing equipment, abilities, and knowledge and making a certain place to learn new abilities to become a creator and establish a community with certain specializations.

Makerspace is a place where creative people can gather, create, create and learn together. In makerspace, library users have access to use 3D printers, audio visual equipment, laser cutters and engravers, sewing machines, cameras and other equipment, both hardware and software that can be used free of charge to create / realize many things based on what is imagined (http://cincinnatilibrary.org/main/makerspac e.html).

Furthermore, makerspace is a continuation of an activity that includes: coworking, hackerspace, and fab lab. In makerspace, for some people, the concept of makerspace is almost identical to the concept of co-working, hackerspace, and fab lab. However, all have different practices. In this case, fab lab is a special room about fabrication which contains about machines, product design workshops, and others. While hackerspace is a space that focuses on computers and technology, programming, website design, and so on. While co-working (collaboratice working) is a development of a hackerspace where co-working becomes a new work style that involves a shared work environment. In co-working, everyone can participate and share anything related to ideas and work and support each other. While makerspace is the home (place) of everything, starting from hackerspace, fab lab, and co-working (Colegrove, 2013: 13).

Thus, it can be concluded that makerspace is a gathering place for creative people to collaborate with each other, share knowledge, and create a work (product) together.

\section{Makerspace in the Library}

Along with the times, the library paradigm as physical space (as place) continues to change. If the first library is only understood as a place for fostering and managing collections, circulation services, references, and administration, then now the paradigm has shifted towards empowering library resources (library resources), empowering users (users), and service innovation (service).

The trend of library services has now shifted. If in the past the library was a quiet place for users in their activities, now the library has become a place for innovative and technology-oriented leaming activities (Priyanto, 2015: 40). On the other hand, the collection space in the library is decreasing and there are more spaces for collaborative works and the convergence of libraries, museums, archives and publishing (Priyanto, 2015: 40). 
One of the new service innovation trends in the library is makerspace. The initial idea to integrate makerspace as a library service stems from school librarians who want to connect between resources in the library with the learning process (Houston, 2013). Makerspace is considered as another way that can create a collaborative and innovative learning climate.

As a recent service innovation in the library, the implementation of makerspace in each library will be very different from one another. This is because, each library can choose one particular topic in making makerspace. However, makerspace has the same potential to produce something extraordinary.

The existence of makerspace increasingly strengthens the position of libraries as public spaces (public spheres) which are the center of community gathering. When referring to Habermas's opinion of public space, he stated that the public sphere at present has experienced degradation caused by the politicization of the authorities and the dominance of modem capitalism. The media and public space become less optimal in carrying out its function as a neutral space for all levels of society to express opinions and access public information (Hendrawan, 2015: 348). With the makerspace, the library has strengthened its position as a neutral public space for every level of society.
One illustration of the real activities of makerspace in the library, for example is when a person reads about robots, he can immediately use robotic tools and practice what he reads. Thus, a child will get a deeper understanding related to robotic knowledge from an early age. He can also be a producer or maker of robots and not just be a consumer. In this case, makerspace encourages someone to be active, collaborate, and create their ideas into a real product (Colegrove, 2013:4).

In the context of the library, the design or types of makerspace can be synchronized with the subject of the library collection. In this case, the existence of a collection becomes a nutritional intake as well as a reference if the makers need new ideas that are relevant in the development of their products. Example on subject 700 (art), the library can provide a focused makerspace for art. Thus, the library can be a place for collaborative learning and create new experiences for users.

\section{Advantages of Makerspace in the Library}

Libraries have long been centers of information and knowledge. The library has an ideal destination for promising projects in the future (Preddy 2013). Librarians continue to look for ways to involve students and the entire academic community in thinking, creating, innovating and developing. Creating a work space that is able to provide freedom in innovation and work in the library makes an effective library 
in the era of all-technology in the era of 5.0. Activities in the library become a fun and inspiring environment outside the constraints of traditional classroom settings. Because academic libraries have maintained critical thinking and learning, they are the perfect environment for space for creation and creation.

\section{Required competence}

According to McNeil \& Giesecke as quoted by Kyungwon Koh \& June Abbas explained that there are some general competencies that must be mastered by librarians in the makerspace era, namely: 1) the ability to learn, 2) the ability to adapt to changing situations (to adapt) to changing situations), 3) the ability to collaborate (to collaborate), 4) the ability to advocate learning (to advocate for the learning), 5) the ability to serve a variety of people (Koh \& Abbas, 2015: 119).

First, the ability to learn. A librarian must have the ability to learn and have a positive attitude in learning something new. In this case, a librarian must think open mindedly. In the context of makespace, the existence of technology and tools used in makerspace also continues to grow. For this reason, librarians must continue to learn and upgrade their knowledge about new things that can be applied to makerspace.

Second, the ability to adapt to changing situations. In this world, everything can change at any time, from tasks, job responsibilities, natural situations, technological developments, and so on. For this reason, a professional librarian must have the ability to adapt to change. Makerspace will continue to grow in line with the times. For this reason, professionalism must be supported by the ability to adapt to the needs of the times.

Third, the ability to collaborate. To create something extraordinary, someone needs a collaboration. Not everything can be done alone. This is in accordance with human nature that he is a social creature in which its existence always requires another human being. Likewise, to build a makerspace. A librarian must collaborate with other parties to provide a new color in the library with the makerspace. However, makerspace is a gathering place for makers to produce a new product so that sharing ideas from various parties with different disciplines is needed. A librarian can collaborate with makers to develop an idea and work on a new project. This is where the importance of the ability to collaborate.

Fourth, the ability to advocate (accompany) the learning process on makerspace. A librarian in this case must be able to provide an understanding to the community that the existence of a library can be an appropriate place of learning to improve one's abilities in a particular field through makerspace.

Fifth, the ability to serve various walks of life. In this case, a librarian knows the diversity of community characters, 
ranging from cultural background, abilities, age, gender, and others. This is so that the learning process in makerspace can work well. Each person with a different character will be different in their way of learning and thinking. Everyone in makerspace must feel comfortable leaming with different individuals. For this reason, a librarian must be able to serve all people.

In addition to mastering general competencies, Kyungwon Koh \& June Abbas also explained the special abilities that must be mastered by librarians in makerspace, namely: 1) managerial skills; 2) program development; 3) fundraising; 4) technological literacy; and 5) facilitation of learning based on the theory and behavior of users (community) (Koh \& Abbas, 2015: 121).

First, managerial ability. In managing makerspace in the library requires good managerial skills. Managerial here is not only managerial in general, but also includes HR management, program management, spatial management, and also information management. Second, program development. A librarian needs skill and knowledge in developing learning resources in makerspace. In this case, the program development capability also includes the development of a learning curriculum, making a prototype of the makerspace, and holding various activities such as workshops.

Third, fundraising. Fundraising is an important skill that must be possessed by a librarian. Fundraising is the main key in management. Whether or not the activity takes place in the makerspace management depends on the extent of the fundraising skill possessed by the librarian. However, to build makerspace requires a lot of funding that includes facilities and infrastructure that is in it.

Fourth, technological literacy. Technology literacy is an important ability that must be had in makerspace. Soft skills and knowledge of the technology itself can support the existence of makerspace. With technology literacy, librarians can determine the right application or technology for the types of makerspace in the library. For example, if makers in makerspace make robots, then a librarian must also know what tools are needed in the manufacturing process. For this reason, technological literacy is needed in the development of makerspace in libraries.

Fifth, facilitate learning. In makerspace, a librarian does not only serve the user, but must also be able to provide facilitation and assistance in learning. Here, the librarian acts as an educator and also a mentor armed with the knowledge and skills possessed. Librarians can also become consultants in certain fields if there are difficulties faced by the user.

Makerspace: A Continuity Basically, makerspace is a gathering space for makers to collaborate and exchange ideas to produce something. Alyssa Pisarski (2014: 13) in his 
paper entitled Finding a place for tween; Makerspace and Libraries write: "Makerspaces consistency of a community of makers that come together to create by sharing tools, skills, and knowledge - creating a place to learn a new skill, to become a creator, to connect with a community and build friendships, or to gain access to specialized equipment, "From this it can be understood that makerspace consists of a community of makers who come together to make things by sharing equipment, abilities, and knowledge and making a certain place to learn new abilities to become a creator and establish communities with certain specializations.

In makerspace, for some people, the concept of makerspace is almost identical to the concept of co-working, hackerspace, and fab lab. However, all have different practices. In this case, fab lab is a special room about fabrication which contains about machines, product design workshops, and others. While hackerspace is a space that focuses on computers and technology, programming, website design, and so on. While co-working (collaboratice working) is a development of a hackerspace where co-working becomes a new work style that involves a shared work environment. In co-working, everyone can participate and share anything related to ideas and work and support each other. While makerspace is the home (place) of everything, starting from hackerspace, fab lab, and coworking (Colegrove, 2013: 13). Thus, it can be concluded that makerspace is a gathering place for creative people to collaborate with each other, share knowledge, and create a work (product) together.

Makerspace in the Library Along with the times, the paradigm of the library as physical space (as place) continues to change. If the first library is only understood as a place for fostering and managing collections, circulation services, references, and administration, then now the paradigm has shifted towards empowering library resources (library resources), empowering users (users), and service innovation (service). The trend of library services has now shifted. If in the past the library was a quiet place for users in their activities, now the library has become a place for innovative and technology-oriented learning activities (Priyanto, 2015: 40). On the other hand, the collection space in the library is decreasing and there are more spaces for collaborative works and the convergence of libraries, museums, archives and publishing (Priyanto, 2015: 40). One of the new service innovation trends in the library is makerspace.

The initial idea to integrate makerspace as a library service stems from school librarians who want to connect between sources in Makerspace: New Trends in Library Services in 33 libraries with the learning process (Houston, 2013). Makerspace is considered as another way that can create a collaborative and innovative learning climate. As a recent service innovation in the library, the implementation of makerspace in each library will be very different from one another. This is because, each library can choose one particular topic in making makerspace. 
However, makerspace has the same potential to produce something extraordinary. In the concept of knowledge management, the existence of makerspace in the library can be one way to make explicit knowledge that so far is still stored in the head (tacit knowledge). With the makerspace, someone in the library can not only read it. But it can practice what is read in makerspace. They can exchange ideas to create something. In makerspace there is an expression, Imagine it! Do it! This shows that in makerspace a person is not only free to imagine, but can also express it in real work.

The existence of makerspace increasingly strengthens the position of libraries as public spaces (public spheres) which are the center of community gathering. When referring to Habermas's opinion of public space, he stated that the public sphere at present has experienced degradation caused by the politicization of the authorities and the dominance of modem capitalism. The media and public space become less optimal in carrying out its function as a neutral space for all levels of society to express opinions and access public information (Hendrawan, 2015: $348)$.

With the makerspace, the library has strengthened its position as a neutral public space for every level of society. One illustration of the real activities of makerspace in the library, for example is when a person reads about robots, he can immediately use robotic tools and practice what he reads. Thus, a child will get a deeper understanding related to robotic knowledge from an early age. He can also be a producer or maker of robots and not just be a consumer. In this case, makerspace encourages someone to be active, collaborate, and create their ideas into a real product (Colegrove, 2013: 4).

In the context of the library, the design or types of makerspace can be synchronized with the subject of the library collection. In this case, the existence of the collection becomes a Makerspace: New Trends in Services at the Library 34 nutrition intake as well as a reference if the makers need new ideas that are relevant in the development of their products. Example on subject 700 (art), the library can provide a focused makerspace for art. Thus, the library can be a place for collaborative learning and create new experiences for users.

Required Competencies According to McNeil \& Giesecke as quoted by Kyungwon Koh \& June Abbas explained that there are some general competencies that must be mastered by librarians in the makerspace era, namely: 1) the ability to leam, 2) the ability to adapt to changing situations (to adapt to changing situations), 3) the ability to collaborate (to collaborate), 4) the ability to advocate learning (to advocate for the learning), 5) the ability to serve a variety of people (Koh \& Abbas, 2015: 119). First, the ability to learn. A librarian must have the ability to learn and have a positive attitude in learning something new. In this case, a librarian must think open mindedly. In the context of makespace, the existence of technology and tools used in makerspace also continues to grow. For this reason, librarians must continue to learn and upgrade their 
knowledge about new things that can be applied to makerspace.

Second, the ability to adapt to changing situations. In this world, everything can change at any time, from tasks, job responsibilities, natural situations, technological developments, and so on. For this reason, a professional librarian must have the ability to adapt to change. Makerspace will continue to grow in line with the times. For this reason, professionalism must be supported by the ability to adapt to the needs of the times. Third, the ability to collaborate. To create something extraordinary, someone needs a collaboration.

Not everything can be done alone. This is in accordance with human nature that he is a social creature in which its existence always requires another human being. Likewise, to build a makerspace. A librarian must collaborate with other parties to provide a new color in the library with the makerspace. However, makerspace is a gathering place for makers to produce a new product that is needed.

\section{Makerspace: New Trends in Services in the}

\section{Library}

the sharing of ideas from various parties with different disciplines of knowledge.

A librarian can collaborate with makers to develop an idea and work on a new project. This is where the importance of the ability to collaborate. Fourth, the ability to advocate (accompany) the learning process on makerspace. A librarian in this case must be able to provide an understanding to the community that the existence of a library can be an appropriate place of leaming to improve one's abilities in a particular field through makerspace. Fifth, the ability to serve various walks of life.

In this case, a librarian knows the diversity of community characters, ranging from cultural background, abilities, age, gender, and others. This is so that the learning process in makerspace can work well. Each person with a different character will be different in their way of learning and thinking. Everyone in makerspace must feel comfortable learning with different individuals. For this reason, a librarian must be able to serve all people. In addition to mastering general competencies, Kyungwon Koh \& June Abbas also explained the special abilities that must be mastered by librarians in makerspace, namely: 1) managerial skills; 2) program development; 3) fundraising; 4) technological literacy; and 5) facilitation of learning based on the theory and behavior of users (community) (Koh \& Abbas, 2015: 121). First, managerial ability. In managing makerspace in the library requires good managerial skills.

Managerial here is not only managerial in general, but also includes HR management, program management, spatial management, and also information management. Second, program development. A librarian needs skill and knowledge in developing learning resources in makerspace. In this case, the program development capability also includes the development of a learning curriculum, making a prototype of the 
makerspace, and holding various activities such as workshops.

Third, fundraising. Fundraising is an important skill that must be possessed by a librarian. Fundraising is the main key in management. Whether or not the activity takes place in the makerspace management depends on the extent of the fundraising skill possessed by the librarian. However, to build makerspace requires a lot of funding that includes facilities and infrastructure that is in it. Makerspace: New Service Trends in Libraries 36 Fourth, technological literacy. Technology literacy is an important ability that must be had in makerspace. Soft skills and knowledge of the technology itself can support the existence of makerspace. With technology literacy, librarians can determine the right application or technology for the types of makerspace in the library. For example, if makers in makerspace make robots, then a librarian must also know what tools are needed in the manufacturing process. For this reason, technological literacy is needed in the development of makerspace in libraries. Fifth, facilitate learning.

In makerspace, a librarian does not only serve the user, but must also be able to provide facilitation and assistance in learning. Here, the librarian acts as an educator (educator) and also a companion (mentor) armed with the knowledge and skills possessed. Librarians can also become a consultant in a particular field if there are difficulties faced by the user. The following are various kinds of collection facilities in the
Batusangkar IAIN library that currently take advantage of space:

\section{CONCLUSION}

In the past, the library was a quiet and quiet place for visitors with a variety of activities, but now the library has turned into innovative, collaborative, and technologyoriented learning spaces. The library's physical collection is increasing and decreasing so that there is additional space that can be used as a library activity.

Makerspace is a new trend in libraries. Makerspace is a gathering place for creative people to share ideas, collaborate and create a work (product) in it. With the makerspace in the library, users will get deep insights as well as experiences about certain topics. One simple example is when a child reads a book about robotics, he can directly hold and use robotic equipment to create a work. They will have a deep understanding of robotics.

The existence of makerspace increasingly strengthens the position of libraries as public spaces (public spheres) which are the center of community gathering. Furthermore, there are several competencies that must be possessed by librarians in the makerspace era in the library, namely: 1) the ability to learn, 2) the ability to adapt to changing situations (to adapt to changing situations), 3) the ability to collaborate (to collaborate), 4) the ability to advocate for learning (to advocate for the learning), 5) the ability to serve a variety of people. In addition, a librarian must also 
have special competencies (soft skills) which include: 1) managerial ability; 2) program development; 3) fundraising; 4) technological literacy; and 5) facilitation of learning based on user (society) theory and behavior.

\section{REFERENCES}

Colegrove, Tod. (2013). "Editorial Board Thoughts: Libraries as Makerspace?" dalam Information Technology and Libraries, p.13

Dian, Arya. (2011). Metamorfosa Paradigma Perpustakaan: Dari not for profit sector menuju income generating unit dengan pemasaran perpustakaan. EduLib, 1(1). 27-38.

Hendrawan, M. R. (2015). Peran Perpustakaan Umum dalam Membangun Masyarakat Informasi: Sebuah Telaah Ruang Publik Jurgen Habermas, dalam Prosiding Semiloka Nasional Kepustakawanan Indonesia 2015.

Houston, Cynthia R. (2013). "Ma (Placeholder1) kerspace@your School Library: Consider the Possibilities".pdf, IASL Conference p.360

Koh, Kyungwon. \& Abbas, J. (2015). Competencies for Information Professionals in Learning Labs and Makerspaces. Journal of Education for Library and Information Science, $56(2)$.
Mursyid, Moh. (2016). Marketspace: Trend Baru Layanan di Perpustakaan. Jurnal Ilmu Perpustakaan dan Informasi (JIPI), 1(1). 29-37. https://www.neliti.com/id/publicatio ns/162778/makerspace-tren-baru-

layanan-di-perpustakaan diakses tanggal 08 Februari 2020.

Pisarski, Alyssa. (2014). Finding a place for tween; Makerspace and Libraries. Jurnal Fall: Children and Libraries, 2014.

Priyanto, I. F. (2015). Librarians, space, and the Atmosphere. Prosiding Semiloka Nasional Kepustakawanan Indonesia 2015

Reza, M., Adlan, H., dkk. (2018). Impelemntasi Repair Café di Perpustakaan Umum. Literasi Digital untuk merawat Kebhinekaan. 20 Oktober 2018. https://www.academia.edu/38621899 /Implementasi_Repair_Cafe_di_Perp ustakaan_Umum diakses pada 10 Februari 2020.

Romi, F. S. (2020). Menuju Perpustakaan Ideal Berdasarkan Undang-undang dan peraturan, (Online), (http://www.bpkp.go.id/pustakabpkp /index.php? $\mathrm{p}=$ perpustakaan $\% 20$ ideal , diakses 10 Februari 2020)

Semiloka Kepustakawanan Indonesia (2016), Kamis 13 Oktober 2016 di Perpustakaan UGM. Perubahan Paradigma Perpustakaan Menghadapi Tantangan Era Digital. 